\title{
Range and natural history of point-tailed palmcreepers (Aves: Furnariidae)
}

\author{
Leonardo Esteves Lopes ${ }^{\mathrm{a} *}$ and Iubatã Paula de Faria ${ }^{\mathrm{b}}$ \\ ${ }^{a}$ Laboratório de Biologia Animal, Universidade Federal de Viçosa - Campus Florestal, Florestal, \\ Brazil; ${ }^{b}$ Programa de Pós Gradução em Ecologia e Conservação, Centro de Ciências Biológicas e \\ da Saúde, Universidade Federal do Mato Grosso do Sul, Campo Grande, Brazil
}

(Received 3 August 2013; accepted 31 October 2013; first published online 24 February 2014)

\begin{abstract}
The point-tailed palmcreeper Berlepschia rikeri is a distinctive Furnariidae species, very shy and poorly known. In this paper we present natural history notes on this species as well as a detailed review of its range. This paper summarizes anecdotal observations gathered during 10 years of ornithological investigation of the central Brazilian Cerrado, as well as data obtained in 13 Brazilian and overseas collections and from online databases. We found that B. rikeri is widely distributed across north and central South America, where it is strictly associated with palm groves, especially those of Mauritia spp. and Orbignya phalerata. Despite being a habitat specialist, this species can be found in a wide spectrum of vegetation formations, from lowland rainforests to high plateau grasslands. This is an insectivorous species, which constructs a stick nest concealed within the fronds of Mauritia palms. Its juvenile plumage is similar to that of the adult.
\end{abstract}

Keywords: breeding; diet; habitat; plumage

\section{Introduction}

The point-tailed palmcreeper Berlepschia rikeri is a large Furnariidae, rare to locally uncommon in palm stands, occurring in both savannah-like and forested areas (Remsen 2003; Restall et al. 2006; Ridgely and Tudor 2009). Berlepschia is a distinctive taxon, currently treated in its own monotypic subfamily (Ohlson et al. 2013). This is a shy and inconspicuous species, not very vocal, but with an unmistakable song that reveals its presence (Remsen 2003; Ridgely and Tudor 2009). Very little is known about its natural history (Remsen 2003), and even its range is imperfectly known, with remarkable range extensions being published recently (e.g. Lopes et al. 2008, 2009). In this paper we present 13 new records of point-tailed palmcreepers from the central Brazilian Cerrado (a kind of tropical savannah), presenting notes on its natural history.

\section{Material and methods}

This paper is the result of opportunistic observations conducted during 10 years of biological investigation of the Brazilian Cerrado. We performed a wide literature review and examined specimens in the following Brazilian and overseas collections:

*Corresponding author. Email: leo.cerrado@gmail.com 
American Museum of Natural History, New York (AMNH); Carnegie Museum of Natural History, Pittsburgh (CM); Universidade Federal de Minas Gerais, Belo Horizonte (DZUFMG); Louisiana State University Museum of Natural Science, Baton Rouge (LSUMZ); Museu de Zoologia, Universidade de São Paulo, São Paulo (MZUSP); Museu Nacional, Rio de Janeiro (MNRJ); Museu Paraense Emílio Goeldi, Belém (MPEG); Museum für Naturkunde, Berlin (ZMB); Muséum National D'Histoire Naturelle, Paris (MNHN); Natural History Museum, Tring (BMNH); Naturhistoriska Riksmuseet Stockholm (NRM); Senckenberg Naturmuseum, Frankfurt (SMF) and Zoologische Staatssammlungen Museum, Munich (ZSM). We also checked for noteworthy records in: (1) two online museum databases (http://www.ornisnet.org/ and http://splink.cria.org.br/); (2) three sound archives (http://www.xeno-canto.org, http://macaulaylibrary.org/index.do and http:// proj.lis.ic.unicamp.br/fnjv/) and (3) one photo archive (http://www.wikiaves.com.br/). All online resources were accessed on 13 February 2013. This paper also benefited from information contained on the labels of specimens deposited in the Yale University Peabody Museum, New Haven (YPM), which we were unable to visit.

\section{Results and discussion}

\section{Body weight}

Given that the most basic data are lacking for this species, we present unpublished data on the body weight of point-tailed palmcreepers obtained from museum labels of specimens deposited in DZUFMG, LSUMZ, MPEG, MZUSP and YPM. Differences in body weight between males $(34.4 \pm 2.4 \mathrm{~g}$, ranging from 28.5 to $37.5 \mathrm{~g}, n=25)$ and females ( $34.3 \pm 3.4 \mathrm{~g}, 28.5$ to $43.0 \mathrm{~g}, n=19)$ were not statistically significant ( $t$-test, $\mathrm{df}=42, p=0.885$, all specimens from Brazil and Surinam). The mean body weight of five other Surinam birds was $37 \mathrm{~g}$ (Dunning 2008).

\section{Range}

The range of point-tailed palmcreepers was said to be "not well known" (Vaurie 1980), which can be attributable not only to its secretiveness, but also to the fact that it inhabits swampy areas, generally poorly sampled by earlier collectors and ornithologists. For example, although the point-tailed palmcreeper was discovered in the Brazilian Cerrado only in the 1990s (Silva 1995), this species was subsequently recorded in dozens of localities in central Brazil after its voice became widely known by ornithologists (Lopes et al. 2008). Here we summarize new records obtained by us and colleagues. Except when indicated, all records were obtained by the authors of this paper: BAHIA: Fazenda São Francisco $\left(13^{\circ} 37^{\prime} \mathrm{S}, 4^{\circ} 58^{\prime} \mathrm{W}\right.$,

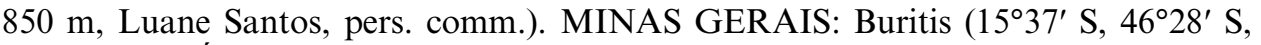
$940 \mathrm{~m})$. GOIÁS: Acreúna $\left(17^{\circ} 05^{\prime} \mathrm{S}, 50^{\circ} 25^{\prime} \mathrm{W}, 780 \mathrm{~m}\right)$, Colinas do Sul $\left(14^{\circ} 09^{\prime} \mathrm{S}, 48^{\circ}\right.$ $\left.06^{\prime} \mathrm{W}, 525 \mathrm{~m}\right)$, Córrego Buriti Torto, Emas National Park $\left(18^{\circ} 06^{\prime} \mathrm{S}, 52^{\circ} 55^{\prime} \mathrm{W}\right.$, $550 \mathrm{~m})$, Córrego dos Ingleses, Chapada dos Veadeiros $\left(14^{\circ} 09^{\prime} \mathrm{S}, 47^{\circ} 46^{\prime} \mathrm{W}\right.$, $1160 \mathrm{~m})$, road between municipalities of Indiara and Edéia $\left(17^{\circ} 24^{\prime} \mathrm{S}, 4^{\circ} 59^{\prime} \mathrm{W}\right.$, $513 \mathrm{~m}$ ), Fazenda Azul, Paraúna (16 $57^{\prime} \mathrm{S}, 50^{\circ} 27^{\prime} \mathrm{W} 730 \mathrm{~m}$ ), Mulungu, Chapada dos Veadeiros $\left(14^{\circ} 04^{\prime} \mathrm{S}, 4^{\circ} 39^{\prime} \mathrm{W}, 1260 \mathrm{~m}\right)$. MATO GROSSO: Lagoa Santa Rosa, Água Boa (14 $11^{\prime} \mathrm{S}, 51^{\circ} 38^{\prime} \mathrm{W}, 245 \mathrm{~m}$, Vívian Braz, pers. comm.). PARÁ: Campo de 
Provas Brigadeiro Veloso, Serra do Cachimbo (09² $\left.22^{\prime} \mathrm{S}, 54^{\circ} 54^{\prime} \mathrm{W}, 480 \mathrm{~m}\right)$. TOCANTINS: Araguacema $\left(08^{\circ} 52^{\prime} \mathrm{S}, 4^{\circ} 28^{\prime} \mathrm{W}, 195 \mathrm{~m}\right)$, Muricilândia $\left(07^{\circ} 14^{\prime} \mathrm{S}\right.$, $\left.48^{\circ} 35^{\prime} \mathrm{W}, 235 \mathrm{~m}\right)$. The new records presented here, together with recently published ones, have resulted in remarkable range extensions for this species (Figure 1), demonstrating that it is fairly common in central Brazil where the appropriate habitat is present. A list of the occurrences of this species is available online as Supplementary Material.

\section{Habitat}

Point-tailed palmcreepers are said to be "ultra habitat-specialists", because they are strictly tied to palm stands, spending most of their time hidden in the top of palms

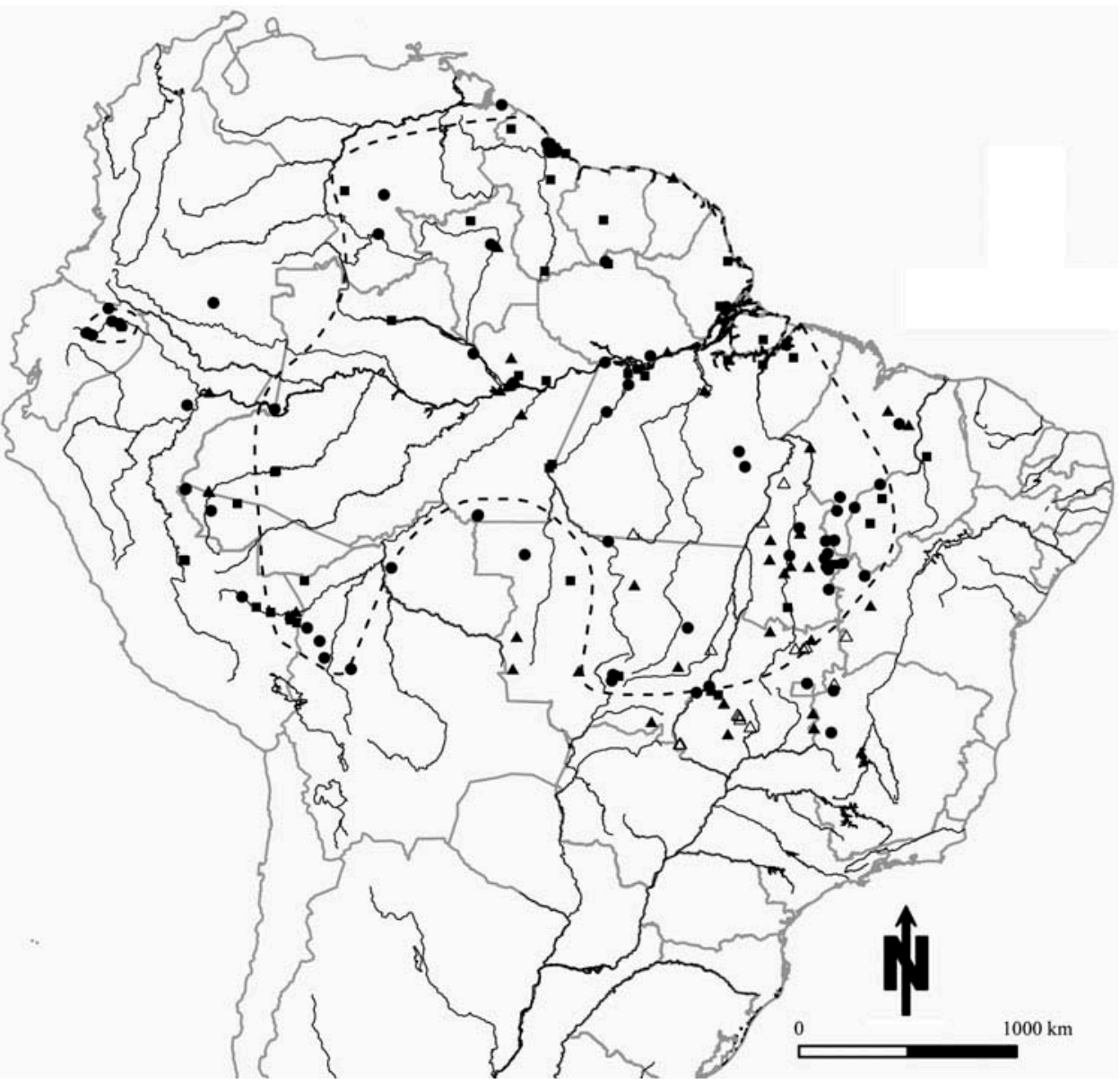

Figure 1. Range of point-tailed palmcreepers Berlepschia rikeri based on a wide review of the literature (dark circles), personally examined museum specimens (dark squares), online databases (dark triangles) and unpublished field records (white triangles). The dashed line indicates the range of this species according to Ridgely and Tudor (2009). 
(Hilty 2002), rarely perching in other tree species (pers. obs.). Preferred palm species are those from the genus Mauritia (Olalla 1935; Sick 1979), which forms dense groves in permanent swamps in Amazonian rainforests as well as in the savannahs of central Brazil (Cerrado) and northern South America (e.g. Llanos and Sipaliwini) (Kahn 1991; Ribeiro and Walter 2008). This palm also occurs on hydromorphic soils along narrow water courses in central Brazil (Ribeiro and Walter 2008) in a linear swamp formation known as "veredas" (see Tubelis 2009 for a review on the birds associated with this vegetation physiognomy).

Point-tailed palmcreepers are also found in stands of the babassu palm Orbignya phalerata (note that the nomenclature of this species is controversial, and that the name Attalea speciosa is also used for it); this species spontaneously forms pure stands on sites where the original forest covering has been logged (Anderson and Balick 1988). This habitat is largely available in the Brazilian states of Maranhão, Tocantins, Goiás and Mato Grosso, where high-density stands of $O$. phalerata are common (Anderson and Balick 1988). Consequently, point-tailed palmcreepers may benefit from forest logging, even living in man-made pastures where the babassu palm is an invasive species (Lopes et al. 2009).

This species seems to live, exceptionally, in other palm species. Snethlage (1906) claimed to have collected it in coconut trees, but Olalla (1935) was sceptical, saying that this species only perches occasionally in this palm, but does not live on it. This species was observed on royal palms in Guyana (Snyder 1966) and on Bactris spp. palms in Ecuador (Ridgely and Greenfield 2001).

Point-tailed palmcreepers are said to be found mostly below $400 \mathrm{~m}$ and locally to $650 \mathrm{~m}$ (Remsen 2003), but they occur at much higher elevations in Central Brazil. This species is found at $1000 \mathrm{~m}$ in Distrito Federal (Bagno 1998) and as high as $1300 \mathrm{~m}$ in the Chapada dos Veadeiros, northern Goiás (pers. obs.). Therefore, although the point-tailed palmcreeper is strictly tied to palm groves, it can be found in a wide range of vegetation formations, from lowland rainforests to the high plateau grasslands of central Brazil.

\section{Breeding}

The nest of this species in unknown (Remsen 2003), but Vaurie (1980) suggested that it is "probably constructed within the fronds of the palms, perhaps in the dead hanging leaves". A breeding pair was observed on 15 March 1989 in Ecuador (Ridgely and Greenfield 2001), but no further details were presented.

IPF observed a breeding pair attending a stick nest concealed within dead leaves hanging from a Mauritia palm (c. $17 \mathrm{~m}$ high) from 27 to 30 October 2006 in the municipality of Colinas do Sul. Because of the difficulty in accessing the nest, its exact structure or content could not be checked, but the nest matched the prediction made by Vaurie (1980).

The breeding pair exhibited strong territorial behaviour, and every day before sunrise, a bird left the nest and perched beside the Mauritia palm where it vocalized intensely for 15-20 minutes. Subsequently, another bird also came and perched close. Both individuals actively defended the nest against other bird species. Two palm tanagers (Thraupis palmarum) were observed (c. 10:00 h) entering the nest, but were chased by the breeding pair after a brief clash. Hours later (c. 14:00 h) the same behaviour was observed, but only one palm tanager entered the nest. In the following 
days, the same interactions were observed between point-tailed palmcreepers and palm tanagers, as well as with the chopi blackbird (Gnorimopsar chopi). We do not know the fate of this nest.

Males with enlarged testes $(n=6)$ were collected in the Brazilian Cerrado from July to November, i.e. from the mid dry season (which extends from May to September) to the beginning of the wet season (October to April) (data from specimens in DZUFMG and MPEG). This pattern is similar to that observed for insectivorous birds in south-central Brazil, where the presence of a brood patch was most common from September to December (Marini and Durães 2001), but with some species starting to breed from July onwards (Lopes and Marini 2005). Males with small testes $(n=5)$ were collected in January, April, July and September). One Bolivian specimen collected in July also had enlarged testes (specimen in LSUMZ).

A juvenile specimen (MZUSP 75300) was collected by L.F. Silveira and G.R. Brito on 21 January 2001 in the Uruçuí-Una Ecological Station, Piauí, Brazil (08 ${ }^{\circ}$ $52^{\prime} \mathrm{S}, 44^{\circ} 58^{\prime} \mathrm{W}$ ), in a Mauritia palm swamp. The juvenile plumage of this species, which is undescribed, is similar to the adult, differing mainly by the extent of black markings in the head and ventral surface (Figure 2). The chin and throat feathers of

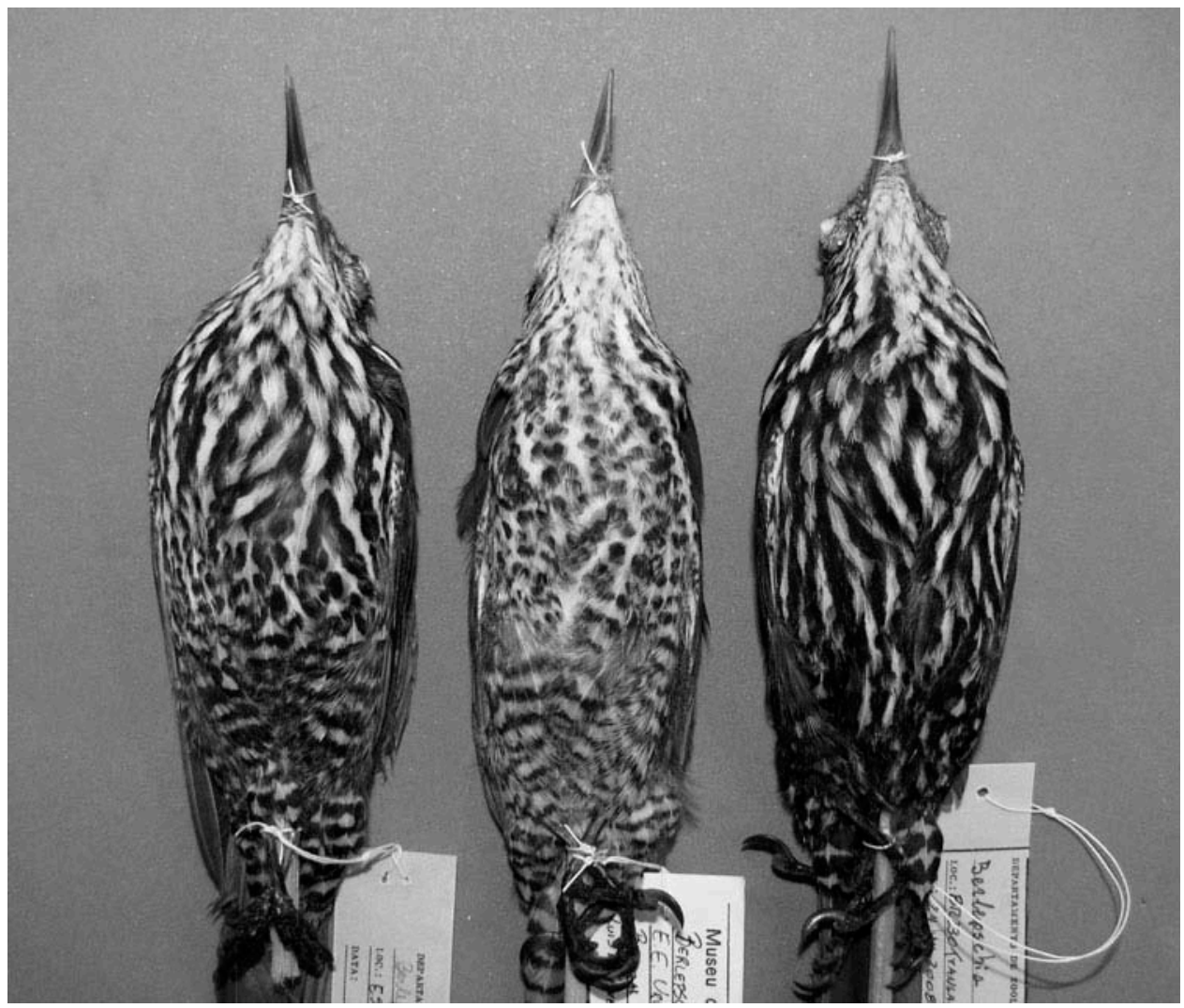

Figure 2. Juvenile plumage (centre, MZUSP 75300, from Piauí) of the point-tailed palmcreeper Berlepschia rikeri showing its distinctiveness when compared with two adult plumaged specimens (left, MZUSP 79659 from Tocantins, and right, MZUSP 84790 from Pará). 
the juvenile bird are almost white, with some small black dots. Its breast and chest feathers' exhibit a similar pattern, but the black dots (two or three pairs per feather) are larger, resulting in a spotted appearance (ventral surface of adult birds is quite distinctive, being mainly black, streaked with white). Belly and under tail coverts of juvenile birds are barred, with white bars being wider than the black bars (in adult birds the black bars are equal in width or wider than the white bars). The heads of juvenile birds have a colour pattern similar to that of adult birds, being mainly black, streaked with white, but the white streaks are wider (c. $1.0 \mathrm{~mm}$ width) than in adult birds (c. $0.5 \mathrm{~mm}$ ). The mantle of juvenile birds also seems to be slightly lighter (near yellowish red 5YR 4/6 of Munsell 2000) than that of adult birds (near dark reddish brown, 5YR 3/4).

\section{Diet}

This is an insectivorous species, but nothing is known about its preferred prey items (Remsen 2003). Opportunistic field observations revealed the consumption of arthropods, including ants, flies and moths. Analyses of the gizzard contents of three specimens deposited in DZUMG revealed an insectivorous diet composed of small arthropods, generally smaller than $5 \mathrm{~mm}$ length, a typical diet for a Furnariidae (Lopes et al. 2005). Preys identified were as follows: DZUFMG 5391 - 2 Hemiptera, 10 Coleoptera, 5 Araneae and 1 Pseudoscorpionida; DZUFMG 5392 - 12 Hemiptera, 27 Coleoptera, 4 Formicidae and 5 Araneae; DZUFMG $5394-1$ Hemiptera, 7 Coleoptera, 2 Formicidae and 9 Araneae. This specimen also ingested two large unidentified insects from which only the mandibles (c. $4 \mathrm{~mm}$ length) remained. Two specimens housed in MPEG contained only arthropods in their gizzards. Seventeen specimens housed in the YPM also contained only arthropods in their gizzards, including Araneae, Orhtoptera, Dictyoptera, Coleoptera and Lepidoptera larvae, confirming the insectivorous diet of this species.

\section{Conservation and further research}

We suggest considering this species as Least Concern because it: (1) has a large extent of occurrence, (2) can live in disturbed habitats and (3) occurs in a large number of protected areas (see Supplementary Material online). This first comprehensive contribution to the natural history of point-tailed palmcreepers will encourage further research. We suggest its territorial and reproductive behaviour as main areas of interest.

\section{Acknowledgements}

LEL received a doctoral fellowship and grants (APQ-04082-10) from the Fundação de Amparo à Pesquisa do Estado de Minas Gerais, also benefiting from a collection study grant from the American Museum of Natural History and grants from the Fundação Arthur Bernardes (FUNARPEX 2010 and 2011, FUNARPEQ 2012). We are grateful to the following museum personnel: Joel Cracraft, Paul Sweet and Margaret Hart (AMNH); Hein van Grouw and Mark Adams (BMNH); Brad Livezey and Stephen Rogers (CM); Marcos Rodrigues (DZUFMG); James Remsen (LSUMZ); Anne Previato (MNHN); Jorge Nacinovic and Marcos Raposo (MNRJ); Luís Fábio Silveira (MZUSP); Alexandre Aleixo and Maria Fátima Lima (MPEG); 
Ulf Johansson and Daniela Kalthoff (NRM); Gerald Mayr (SMF); Storrs Olson and Brian Schmidt (USNM); Sylke Frahnert and Pascal Eckhoff (ZMB) and Markus Unsöld (ZSM). Luane Santos and Vívian Braz shared unpublished records with us. Marcos Lima and Wellington Coelho helped us with the map. IBAMA and ICMBio provided collecting permits. We also thank all those institutions and people that made available online their records through the WikiAves, Xeno-Canto, Macaulay Library, Fonoteca Neotropical Jacques Vielliard, SpeciesLink and ORNIS portals. Two anonymous reviewers presented important contributions to a previous version of this manuscript, providing unpublished data on specimens housed in the YPM.

\section{References}

Anderson AB, Balick MJ. 1988. Taxonomy of the babassu complex (Orbignya spp.: Palmae). Sys Bot. 13:32-50.

Bagno MA. 1998. As aves da Estação Ecológica de Águas Emendadas. In: Marinho-Filho J, Rodrigues F, Guimarães M, editors. Vertebrados da Estação Ecológica de Águas Emendadas: história natural e ecologia em um fragmento de Cerrado do Brasil central. Brasília: SEMATEC, IEMA, IBAMA; p. 22-33.

Dunning JB Jr. 2008. CRC Handbook of avian body masses. 2nd ed. Boca Raton, FL: CRC Press.

Hilty SL. 2002. Birds of Venezuela. 2nd ed. Princeton, NJ: Princeton University Press.

Kahn F. 1991. Palms as key swamp forest resources in Amazonia. For Ecol Manag. 38:133-142.

Lopes LE, Fernandes AM, Marini MÂ. 2005. Diet of some Atlantic Forest birds. Ararajuba. 13:95-103.

Lopes LE, Malacco GB, Vasconcelos MF, Carvalho CEA, Duca C, Fernandes AM, D‘Angelo Neto S, Marini MÂ. 2008. Aves da região de Unaí e Cabeceira Grande, noroeste de Minas Gerais, Brasil. Rev Bras Ornitol. 16:193-206.

Lopes LE, Marini MÂ. 2005. Low reproductive success of Campo Suiriri (Suiriri affinis) and Chapada Flycatcher (S. islerorum) in the central Brazilian Cerrado. Bird Conserv Int. 15:337-346.

Lopes LE, Pinho JB, Bernardon B, Oliveira FF, Bernardon G, Ferreira LP, Vasconcelos MF, Maldonado-Coelho M, Nóbrega PFA, Rubio TC. 2009. Aves da Chapada dos Guimarães, Mato Grosso, Brasil: uma síntese histórica do conhecimento. Pap Avulsos Zool. 49:9-47.

Marini MÂ, Durães RD. 2001. Annual patterns of molt and reproductive activity of Passerines in south-central Brazil. Condor. 115:767-775.

Munsell. 2000. Munsell soil color charts. New York, NY: Gretag Macbeth.

Ohlson JI, Irestedt M, Ericson PGP, Fjeldså J. 2013. Phylogeny and classification of the New World Suboscines (Aves, Passeriformes). Zootaxa. 3613:1-35.

Olalla AM. 1935. El Berlepschia rikeri y su biología. Rev Mus Paulista. 19:419-423.

Remsen JV Jr. 2003. Point-tailed Palmcreeper Berlepschia rikeri. In: Del Hoyo J, Elliott A, Sargatal J, editors. Handbook of the birds of the World, vol. 8, Broadbills to Tapaculos. Barcelona: Lynx Edicions; p. 328.

Restall R, Rodner C, Lentino M. 2006. Birds of northern South America, vol. 1, species account. London: Christopher Helm.

Ribeiro JF, Walter BMT. 2008. As principais fitofisionomias do bioma Cerrado. In: Sano SM, Almeida SP, Ribeiro JF, editors. Cerrado ecologia e flora, vol. 1. Brasília: Embrapa Cerrados; p. 151-212.

Ridgely RS, Greenfield PJ. 2001. The birds of Ecuador, vol. 1, status distribution and taxonomy. Ithaca, NY: Comstock Publishing Associates. 


\section{L.E. Lopes and I.P. de Faria}

Ridgely RS, Tudor G. 2009. Field guide to the songbirds of South America: the passerines. Austin, TX: University of Texas Press.

Sick H. 1979. Notes on some Brazilian birds. Bull Br Ornithol Club. 99:115-120.

Silva JMC. 1995. Birds of the Cerrado Region, South America. Steenstrupia. 21:69-92.

Snethlage E. 1906. Über unteramazonische Vögel [part II). J Ornithol. 54:519-526.

Snyder DE. 1966. The birds of Guyana. Salem, OR: Peadody Museum.

Tubelis DP. 2009. Veredas and their use by birds in the Cerrado, South America: a review. Biota Neotrop. 9:363-374.

Vaurie C. 1980. Taxonomy and geographical distribution of the Furnariidae (Aves, Passeriformes). Bull Am Mus Nat Hist. 166:1-357. 